\title{
Patient blood management: A solution for South Africa
}

J Thomson, ${ }^{1} \mathrm{MB}$ ChB, MMed (Int Med), Cert Clinical Haematology (SA); A Hofmann, ${ }^{2-5}$ Dr rer medic, ME; C A Barrett, ${ }^{6} \mathrm{MB}$ ChB, Dip Transfusion Med, MMed, FCP; A Beeton, ${ }^{7} \mathrm{MB}$ ChB, FFA (SA); G R M Bellairs, ${ }^{8}$ MB ChB, MBA, Dip Transfusion Med; L Boretti, ${ }^{9} \mathrm{PhD}$, MB ChB; M J Coetzee, ${ }^{10}$ MB ChB, MMed (Path), FFPath (SA), DTM\&H; S Farmer, ${ }^{2,4}$ Research Fellow; M W Gibbs, ${ }^{11}$ MB ChB, DA (SA), FCA (SA), MMed (Anaes); H H Gombotz, ${ }^{5,12}$ MD; C Hilton, ${ }^{8}$ MB ChB, Dip HIV Man (SA); C Kassianides, ${ }^{13}$ MB ChB, FCP (SA); V J Louw ${ }^{14}$ MB ChB, MMed (Int Med), PhD (HPE); C Lundgren, ${ }^{7,15}$ MB ChB, FFA (SA), PhD, MSc Med, Health Law and Bioethics; J N Mahlangu, ${ }^{16-18}$ BSc, MB ChB, MMed, FCPath, Cert Clinical Haematology (SA); C B Noel, ${ }^{19}$ FCS (SA), MB ChB, MMed (Surgery), BSc (Med) Hons, ESB, BA (HMS); V Rambiritch, ${ }^{1}$ BTech Biomed, PGDip HPE, MPhil HPE; F Schneider, ${ }^{11}$ MB ChB, FRCA, FANZCA; E Verburgh, ${ }^{14} \mathrm{MD}$, PhD; P-L Wessels, ${ }^{1}$ BMedSc, MB ChB, Dip Transfusion Med; P Wessels, ${ }^{20} \mathrm{MB}$ ChB, MMed (Haem), Cert Clinical Haematology (SA); R Wise, ${ }^{21-23} \mathrm{MB}$ ChB, FCA (SA), MMed (Anaes), Cert Critical Care (SA); A Shander, ${ }^{24,25} \mathrm{MD}$, FCCM, FCCP, FASA; on behalf of the South African Patient Blood Management Group

${ }^{1}$ South African National Blood Service, Johannesburg, South Africa

${ }^{2}$ Medical School and Division of Surgery, Faculty of Health and Medical Sciences, University of Western Australia, Australia

${ }^{3}$ Institute of Anaesthesiology, University Hospital and University of Zurich, Switzerland

${ }^{4}$ School of Health Sciences and Graduate Studies, Faculty of Health Sciences, Curtin University, Bentley, Western Australia, Australia

${ }^{5}$ International Foundation for Patient Blood Management, Basel, Switzerland

${ }^{6}$ Department of Internal Medicine, Faculty of Health Sciences, University of the Free State, Bloemfontein, South Africa

${ }^{7}$ Department of Anaesthesiology, Wits Donald Gordon Medical Centre, Johannesburg, South Africa

${ }^{8}$ Western Province Blood Transfusion Service, Cape Town, South Africa

${ }^{9}$ Department of Anaesthesiology, Port Elizabeth Hospital Complex, South Africa

${ }^{10}$ Department of Haematology and Cell Biology, National Health Laboratory Service and Faculty of Health Sciences, University of the Free State, Bloemfontein, South Africa

${ }^{11}$ Department of Anaesthesiology and Perioperative Medicine, Groote Schuur Hospital and Faculty of Health Sciences, University of Cape Town, South Africa

${ }^{12}$ Department of Anaesthesiology, Intensive Care Medicine and Pain Management, General Hospital Linz, Austria

${ }^{13}$ Department of Medicine, Faculty of Health Sciences, University of Cape Town, South Africa; and Morningside Clinic, Johannesburg, South Africa

${ }^{14}$ Division of Clinical Haematology, Department of Medicine, Faculty of Health Sciences, University of Cape Town, South Africa

${ }^{15}$ Steve Biko Centre for Bioethics, Faculty of Health Sciences, University of the Witwatersrand, Johannesburg, South Africa

${ }^{16}$ School of Pathology, Faculty of Health Sciences, University of the Witwatersrand, and National Health Laboratory Service, Johannesburg, South Africa

${ }^{17}$ World Federation of Haemophilia International Haemophilia Training Centre, Johannesburg, South Africa

${ }^{18}$ Bleeding Disorders Unit and Clinical Haematology Service, Charlotte Maxeke Johannesburg Academic Hospital, Johannesburg, South Africa

${ }^{19}$ Department of General/Transplant Surgery, Groote Schuur Hospital, Cape Town, South Africa

${ }^{20}$ Department of Medical Oncology, Faculty of Health Sciences, University of Pretoria, South Africa

${ }^{21}$ Pietermaritzburg Metropolitan Department of Anaesthetics, Critical Care and Pain Management, Pietermaritzburg, South Africa

${ }^{22}$ Head Clinical Unit, Critical Care, Edendale Hospital, Pietermaritzburg, South Africa

${ }^{23}$ Discipline of Anaesthesiology and Critical Care, School of Clinical Medicine, University of KwaZulu-Natal, Durban, South Africa

${ }^{24}$ Department of Anesthesiology and Surgery, Icahn School of Medicine at Mount Sinai, NY, USA

${ }^{25}$ Team Health Research Institute, Englewood Health, Englewood, NJ, USA

Corresponding author:J Thomson (jackie.thomson@sanbs.org.za)

For more than 70 years the default therapy for anaemia and blood loss was mostly transfusion. Accumulating evidence demonstrates a significant dose-dependent relationship between transfusion and adverse outcomes. This and other transfusion-related challenges led the way to a new paradigm. Patient blood management (PBM) is the application of evidence-based practices to optimise patient outcomes by managing and preserving the patient's own blood. 'Real-world' studies have shown that PBM improves patient outcomes and saves money. The prevalence of anaemia in adult South Africans is $31 \%$ in females and $17 \%$ in males. Improving the management of anaemia will firstly improve public health, secondly relieve the pressure on the blood supply, and thirdly improve the productivity of the nation's workforce. While high-income countries are increasingly implementing PBM, many middle- and low-income countries are still trying to upscale their transfusion services. The implementation of PBM will improve South Africa's health status while saving costs.

S Afr Med J 2019;109(7):471-476. DOI:10.7196/SAMJ.2019.v109i7.13859

For decades the default treatment for anaemia and bleeding was mostly blood transfusion. However, safety risks from new and re-emerging pathogens in the blood pool, ${ }^{[1-3]}$ significant inter- and intrahospital transfusion variability for matched patients, ${ }^{[4-9]}$ the high cost of transfusion therapy, ${ }^{[10,11]}$ and in particular the large number of risk-adjusted observational studies demonstrating that transfusion 
is independently associated in a dose-dependent relationship with adverse outcomes including morbidity and mortality, ${ }^{[12-25]}$ have led to questioning of the transfusion paradigm. ${ }^{[2,27]}$ Also, systematic reviews and meta-analyses of randomised controlled trials have shown either no benefit or increased risks from liberal transfusion regimens when compared with more restrictive regimens. ${ }^{[28-32]}$ In response to these challenges and with the objectives of better addressing the causes or underlying diseases that could potentially lead to allogeneic transfusions and offering the best choice of therapy, the new paradigm of patient blood management (PBM) has emerged.

PBM is described by the International Foundation for Patient Blood Management as an evidence-based bundle of care to optimize medical and surgical patient outcomes by clinically managing and preserving a patient's blood. ${ }^{[33]}$ This is achieved by optimising erythropoiesis, minimising blood loss and harnessing or optimising the physiological reserves of anaemia while appropriate therapy is instituted, often referred to as the 'three pillars of patient blood management' (Fig. 1). This concept was adopted by the World Health Assembly resolution WHA63.12 in 2010. ${ }^{[34]}$ A similar and widely used description of PBM by the Society for the Advancement of Blood Management is 'the timely application of evidence-based medical and surgical concepts designed to maintain hemoglobin concentration, optimize hemostasis and minimize blood loss in an effort to improve patient outcome. ${ }^{\text {'35] }}$

A number of large observational PBM studies have demonstrated significantly improved patient outcomes including mortality, morbidity and average length of hospital stay, ${ }^{[36-39]}$ one of these being a recent 'real-world study' with 605046 patients within the jurisdiction of Western Australia (Table 1). ${ }^{[40]}$ Also, a growing number of randomised controlled trials looking at single PBM treatment modalities showed significantly improved patient outcomes with concurrent reduction of blood component utilisation. ${ }^{[41,42]}$ Overall, PBM has demonstrated improved outcomes while reducing cost and/or resource utilisation (blood components) with the potential to repurpose those savings.

\section{PBM as a standard of care}

PBM has the potential to address several healthcare-related challenges that are specific to South Africa (SA).

First, the population of SA totalled 57.8 million in $2018^{[33]}$ and included an estimated 17.8 million people suffering from anaemia, mostly neonates and children, women of reproductive age, and the elderly. ${ }^{[4-47]}$ Apart from iron deficiency anaemia, there is also a high prevalence of HIV-related anaemia, anaemia of inflammation, malarial anaemia and anaemia from intestinal parasite infestations. In hospitalised patients, the prevalence of anaemia is even higher than in the general population, and it is an independent predictor for adverse outcomes including morbidity and mortality. ${ }^{[48,49]}$ A secondary analysis of the South African Surgical Outcomes Study (SASOS), a large prospective observational study of patients undergoing inpatient non-cardiac, non-obstetric surgery at 50 hospitals across SA over a 7-day period, showed that the prevalence of preoperative anaemia was $47.8 \%$ and that it was independently associated with an increase in in-hospital mortality (odds ratio (OR) $1.657,95 \%$ confidence interval (CI) $1.055-2.602 ; p=0.028)$ and admission to critical care

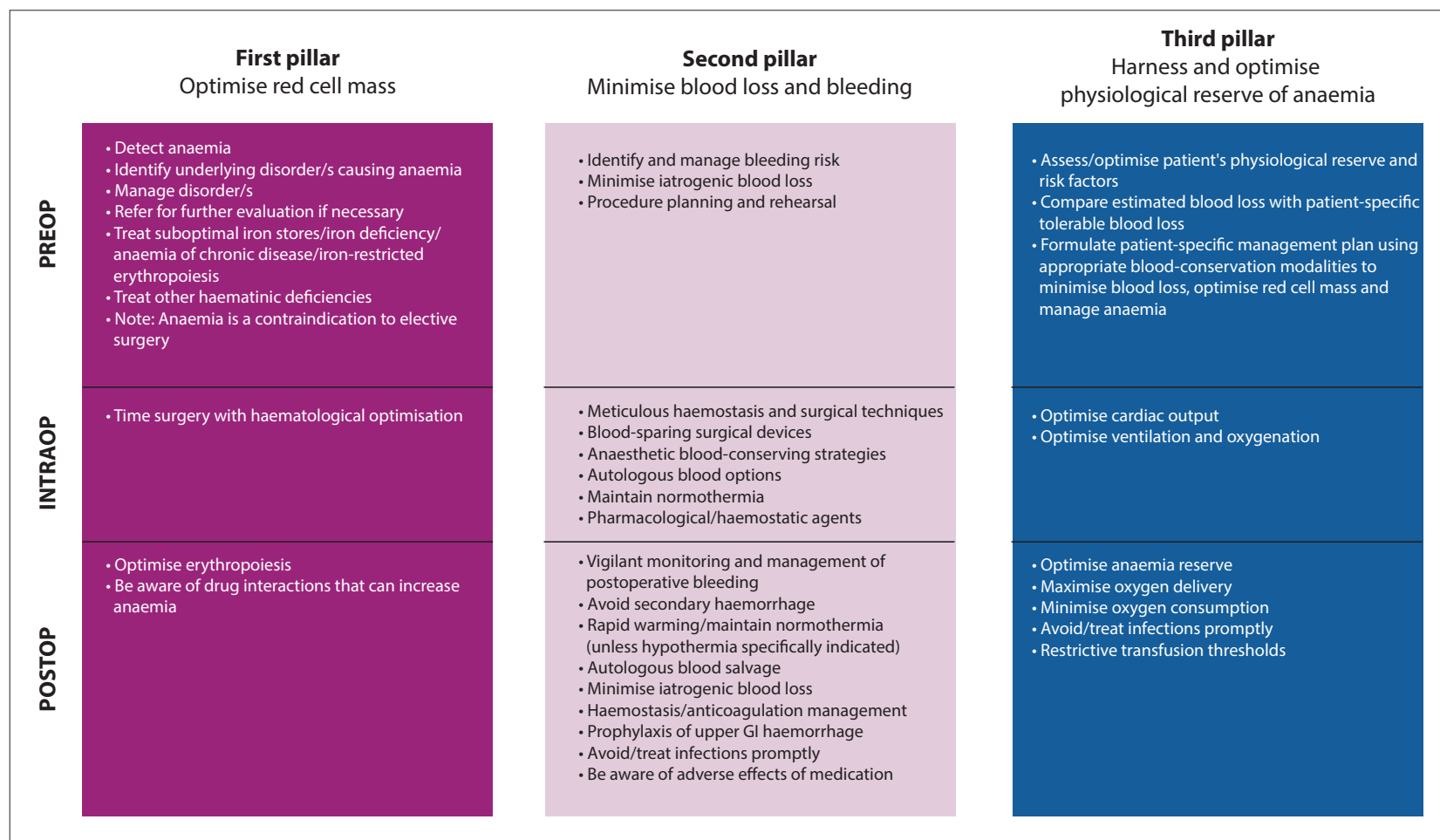

Perioperative multidisciplinary multimodal patient-specific team approach

Fig. 1. The three-pillar, nine-field matrix of PBM. This matrix was designed for the Western Australia Patient Blood Management Program to assist in the clinical implementation of the multiple PBM strategies. These strategies are considered in the perioperative period in a patient-and procedure-specific context. ${ }^{[89]}$ The principles of this matrix were also applied to non-surgical patients before, during and after treatment. (PBM = patient blood management.) 
Table 1. Summary of study results from the Western Australia Patient Blood Management Program, 2008 - 2012 (N=605 046), comparing baseline year $(2008 / 09)$ with year $6(2013 / 14)$ (adapted from Leahy et al..$^{\mid 40]}$ )

\begin{tabular}{|c|c|c|}
\hline Patient outcomes & Adjusted ratios $(95 \% \mathrm{CI})$ & $p$-value \\
\hline In-hospital mortality & $0.72(0.67-0.77)$ & $<0.001$ \\
\hline Hospital-acquired infections & $0.79(0.73-0.86)$ & $<0.001$ \\
\hline Acute myocardial infarction/stroke & $0.69(0.58-0.82)$ & $<0.001$ \\
\hline Length of hospital stay & $0.85(0.84-0.87)$ & $<0.001$ \\
\hline All-cause emergency readmission & $1.06(1.02-1.10)$ & $<0.001$ \\
\hline Key programme indicators & Change & \\
\hline Preoperative anaemia & $21 \%$ to $14 \%$ & 0.001 \\
\hline Pre-transfusion haemoglobin & $7.9 \mathrm{~g} / \mathrm{dL}$ to $7.3 \mathrm{~g} / \mathrm{dL}$ & $<0.001$ \\
\hline Single-unit transfusions & $33 \%$ to $64 \%$ & $<0.001$ \\
\hline Type of blood product & Reduction of units transfused & \\
\hline Red blood cells & $41 \%$ & $<0.001$ \\
\hline Plasma & $47 \%$ & $<0.001$ \\
\hline Platelets & $27 \%$ & $<0.001$ \\
\hline \multicolumn{3}{|l|}{ Economic indicators } \\
\hline Blood product cost reduction & AUD18.5 million & \\
\hline Activity-based cost reduction (estimate) & AUD80 - 100 million & \\
\hline
\end{tabular}

(OR 1.487, 95\% CI $1.081-2.046 ; p=0.015){ }^{[50]}$ For these reasons, the implementation of PBM including anaemia management and bleeding management represents a major opportunity to sustainably improve public health in SA in respect of:

- child mortality

- maternal mortality (particularly related to peri- and postpartum haemorrhage)

- anaemia-related adverse outcomes

- blood loss and bleeding-related adverse outcomes

- transfusion-related adverse outcomes

- overall surgical and medical outcomes in hospitalised patients.

Second, the implementation of PBM would ease the pressure on the nation's blood supply. The high prevalence of anaemia, the high prevalence of HIV with the world's highest absolute number of cases, ${ }^{[51]}$ and other frequently occurring diseases have led to a particularly high rate of $20 \%$ blood donor deferrals (Dr Jaqueline Thomson, Medical Director, South African National Blood Service, personal communication, 2018). At the same time, the demand for blood components is expected to increase owing to HIV-related anaemia and the population segment aged $\geq 65$ years that is now growing faster than previously. ${ }^{[52]}$ As a consequence, the prevalence of chronic disease and surgical procedures is expected to rise, with a concomitant increased demand for blood unless there are immediate and widespread practice changes.

Third, there is also an overall economic argument for the implementation of PBM. Unmanaged or poorly managed anaemia impairs the cognitive development of children and adolescents, reduces the ability to concentrate, and diminishes work productivity with losses in some countries of up to $9 \%$ of the gross domestic product. ${ }^{[33]}$ Programmes promoting oral iron therapy may be effective in specific subpopulations, but in patients with profound iron deficiency and iron deficiency anaemia, who require therapy for immediate correction, an appropriate dose of intravenous iron is the best option, while treatment of the underlying cause produces a cure. ${ }^{[54]}$ Improvements in patient outcomes with the concomitant savings as seen in previous studies could lead to a significant decrease in bed occupation and relieve a healthcare budget under extreme pressure..$^{[42,55]}$

\section{Contradictory developments:} PBM for high-income countries and transfusion for the rest?

In the healthcare systems of the advanced economies, both the private and public sectors have begun to move their focus towards pre-empting the causes for transfusion through PBM rather than expanding the infrastructure to advance transfusion therapy. ${ }^{[56]}$ The full implementation of PBM as a bundle of care is challenging, and some institutions are therefore following the recommendation of a stepwise implementation by introducing a series of simple PBM measures. ${ }^{[57,58]}$ Others are choosing comprehensive change management methodologies and multi-stakeholder management to achieve relatively fast and system-wide implementation. ${ }^{[40]}$ The variable implementation methodologies, and also differences in hospital cultures, may explain why the implementation of PBM remains extremely variable across many of the high-income countries. ${ }^{[59]}$ However, the underlying rationale for this patient-centric approach is simple and compelling: PBM is not only associated with a better outcome, but also with less cost. ${ }^{[36,38,40]}$ Consequently, PBM keeps growing while blood services are experiencing a significant decline in blood utilisation and therefore re-engineer, downsize operations, or merge with other regional blood services. ${ }^{[56,60]}$

In contrast, in many emerging and frontier economies, the focus of health authorities is still on modernising blood services to match quality levels comparable to those in the advanced economies and on establishing additional blood centres. ${ }^{[61-70]}$ This expansion results in significant new investments and adds to the already large expenses of maintaining these services. In view of the poor cost-effectiveness of blood safety interventions and of transfusion therapy, ${ }^{[71-73]}$ it is inappropriate use of limited financial resources. The decision to allocate more resources to supporting the product-focused transfusion model rather than the patient-centric PBM model could be likened to the establishment of landlines in a geographical area bare of communication infrastructure rather than setting up highly effective and much less costly mobile phone networks de novo.

In view of the burgeoning clinical data on adverse transfusion outcomes, the ongoing blood safety issues, the pervasive blood sourcing problems and the overall health-economic constraints, it would be both unethical and paradoxical to continue to invest 
financial and human resources into the fading model of traditional blood banking while neglecting the implementation of PBM. ${ }^{[74]}$

\section{Seizing the opportunity to improve SA's health status and patient safety while saving costs}

With combined support from both the public and private sectors, including the professional medical societies, academia, healthcare providers, funders, blood services and patient organisations and the endorsement of SA's National Department of Health, a guiding coalition of PBM champions should take the opportunity to establish $\mathrm{PBM}$ as a new standard of care that offers a win-win scenario. ${ }^{[75]}$

PBM has become a national priority of the Australian Commission on Safety and Quality in Health Care, ${ }^{[76]}$ and stakeholders in the public and private healthcare sectors of other countries have the opportunity to learn from the results of the state-wide PBM quality, safety and effectiveness initiative in Western Australia that significantly improved outcomes and achieved a sizeable cost and resource utilisation reduction. ${ }^{[40]}$ They may benefit from the freely available multidisciplinary clinical PBM guidelines and algorithms. [77-83] With local adaptations they may also use the European Commission's guides for hospitals and health authorities on how to implement PBM sustainably as a national standard of care. ${ }^{[84,85]}$ Additional lessons can be learned from blood services in foreign countries that are now embracing implementation of PBM as one of their core activities. ${ }^{[86-88]}$

Compelling evidence, newly gained international experience and many freely available tools and templates are now allowing progress to be quickly achieved with a series of single, evidence-based PBM interventions, or preferably PBM pilot programmes to be started in both the public and private sectors, gradually adjusting and refining contents to local needs and finally implementing PBM as a national standard of care.

\section{Discussion}

This article first describes why in many clinical settings the transfusion paradigm is fading while the PBM paradigm is rising. Overall, the evidence demonstrates that correcting anaemia through stimulated erythropoiesis, minimising blood loss through anaesthetic and surgical techniques, and optimising coagulation status before and during surgical or other interventions are associated with significantly better outcomes and less cost than the decades-old practice of transfusing allogeneic blood components. Then, the authors explain why implementation of PBM represents a solution to many of SA's health, healthcare and economic challenges. PBM would effectively reduce the prevalence of anaemia, which owing to the country's specific circumstances is higher than in many other countries. In combination with optimised bleeding and coagulation management, this reduction would have a positive effect on child and maternal mortality. Overall, based on international study results and in the context of secondary analysis of the SASOS, a large number of hospitalised medical and surgical patients would benefit from PBM. Its implementation would also decrease the demand for allogeneic blood components, thus easing the chronic pressure on the nation's blood supply, which has a high number of donor restrictions as a result of HIV-related and other transmissible diseases. PBM would also contribute to socioeconomic improvements. Fewer complications, reduced morbidity and reduced hospital length of stay could lead to significant cost savings that could be reallocated to other areas of unmet clinical need. Optimal anaemia management, central to $\mathrm{PBM}$, would also improve the cognitive development of children and adolescents, thus positively influencing productivity and the gross domestic product and the quality of life in SA.

The authors also allude to an important cultural aspect when it comes to the implementation of PBM: health authorities have traditionally focused on the supply of, not the demand for, blood. For decades, the legislation and administration of the 'blood sector' revolved around the concept that red blood cell transfusion is the only way of treating anaemia and blood loss. Therefore, the permanent and ubiquitous availability of safe donor blood was considered indispensable to keep clinical services operational, while the financial aspects of blood safety measures played only a minor role. However, with the introduction of evidence-based patient and disease management through PBM, other treatment options are now preferred, and in many clinical scenarios, blood transfusions are less frequently used or have even become obsolete.

Although this reversal of trends can now be observed in many modern healthcare systems, it may be challenging for health authorities to change focus, particularly when current efforts are still geared towards expansion of blood services. PBM will clearly impact a lot more on reducing the number of transfused blood components than any effort of the blood centres to increase the number of blood collections.

This article should be understood as a call to action to significantly improve the quality, safety and effectiveness of healthcare in SA. First, health authorities, medical professionals, funders and all other relevant stakeholders need to be thoroughly informed about the evidence on the multiple wins with PBM. This knowledge should lead to their acknowledgement and official endorsement of PBM and active support to implement it. Second, multidisciplinary peerreviewed guidelines, algorithms and other useful tools for PBM, that have already been developed in other parts of the world and are freely accessible, need to be adapted to the local needs of SA. This should primarily take place with the active involvement of all the relevant professional medical societies in SA. Third, PBM pilot projects in the public and private sectors should be carried out to test and refine PBM in the current healthcare framework, and finally, PBM should be implemented as a mandatory national standard of care.

\section{Conclusions}

The rapid implementation of PBM as a new standard of care is an urgent need. It offers the opportunity to sustainably and significantly improve the health status of the people of SA, with the potential of enormous savings for the healthcare system.

\section{Declaration. None.}

Acknowledgements. We gratefully acknowledge David M Mngomezulu, $\mathrm{MD}$, for his insightful comments and his clear call for action regarding the implementation of PBM in SA.

Author contributions. JT and AH contributed equally to this article. JT, AH, RW and AS conceptualised and wrote the manuscript. CAB, AB, GRMB, LB, MWG, HHG, CH, CK, VJL, CL, CBN, VR, FS, EV, P-LW and PW reviewed and edited the manuscript. $\mathrm{SF}$ reviewed and edited the manuscript and jointly with $\mathrm{AH}$ provided the figure and table data. JNM and MJC reviewed and edited the manuscript and helped prepare it for submission. Funding. None.

Conflicts of interest. JT has received honoraria from Takeda. AH has received honoraria and travel support from Vifor, Fresenius, Medical Care Renal and Werfen and travel support from the South African National Blood Service. VJL has received honoraria and travel support from Litha Healthcare, Pharmacosmos, Takeda and Vifor Pharma, and is also a 
non-executive director of the Western Cape Blood Service. AS reports grants from CSL Behring, $\mathrm{HbO} 2$ Therapeutics, LLC, Instrumentation Laboratory and Masimo Corporation, has received honoraria from CSL Behring, Masimo Corporation, Merck and Portola Pharmaceuticals, and has been a consultant for AMAG, CSL Behring, HbO2 Therapeutics, LLC, Instrumentation Laboratory, Masimo Corporation, Portola Pharmaceuticals and Vifor Pharma. There are no conflicts of interest for the other authors.

1. Alter HJ, Stramer SL, Dodd RY. Emerging infectious diseases that threaten the blood supply. Semin Hematol 2007;44(1):32-41. https://doi.org/10.1053/j.seminhematol.2006.09.016

2. Stramer SL, Hollinger FB, Katz LM, et al. Emerging infectious disease agents and their potential threat to transfusion safety. Transfusion 2009;49(Suppl 2):1S-29S. https://doi.org/10.1111/j.15372995.2009.02279.x

3. Snyder EL, Stramer SL, Benjamin RJ. The safety of the blood supply - time to raise the bar. N Engl J 3. Snyder EL, Stramer SL, Benjamin RJ. The safety of the blood supply -
Med 2015;372(20):1882-1885. https://doi.org/10.1056/NEJMp1500154

4. Stover EP, Siegel LC, Parks R, et al. Variability in transfusion practice for coronary artery bypass surgery persists despite national consensus guidelines: A 24-institution study. Institutions of the Multicenter Study of Perioperative Ischemia Research Group. Anesthesiology 1998;88(2):327-333.

5. Bennett-Guerrero E, Zhao Y, O'Brien SM, et al. Variation in use of blood transfusion in coronary arter bypass graft surgery. JAMA 2010;304(14):1568-1575. https://doi.org/10.1001/jama.2010.1406

6. Snyder-Ramos SA, Mohnle P, Weng YS, et al. The ongoing variability in blood transfusion practices in cardiac surgery. Transfusion 2008;48(7):1284-1299. https://doi.org/10.1111/j.1537-2995.2008.01666.x
. Gombotz H, Rehak PH, Shander A, Hofmann A. Blood use in elective surgery: The Austrian benchmark study. Transfusion 2007;47(8):1468-1480. https://doi.org/10.1111/j.1537-2995.2007.01286.x

8. Baele PL, de Bruyere M, Deneys V, et al. The SANGUIS Study in Belgium: An overview of methods and results. Safe and good use of blood in surgery. Acta Chir Belg 1994;94(2):69-74.

9. Zhu C, Gao Y, Li Z, et al. A systematic review and meta-analysis of the clinical appropriateness of blood Transfusion in China. Medicine 2015;94(50):e2164. https:///doi.org/10.1097/MD.0000000000002164
the

10. Shander A, Hofmann A, Ozawa S, Theusinger OM, Gombotz H, Spahn DR. Activity-based costs of Shander A, Hofmann A, Ozawa S, Theusinger OM, Gombotz H, Spahn DR. Activity-based costs of
blood transfusions in surgical patients at four hospitals. Transfusion 2010;50(4):753-765. https://doi. blood transfusions in surgical patients
org $/ 10.1111 / j .1537-2995.2009 .02518 . x$

11. Shander A, Ozawa S, Hofmann A. Activity-based costs of plasma transfusions in medical and surgical inpatients at a US hospital. Vox Sang 2016;111(1):55-61. https://doi.org/10.1111/vox.12386

12. Whitlock EL, Kim H, Auerbach AD. Harms associated with single unit perioperative transfusion: Retrospective population based analysis. BMJ 2015;350:h3037. https://doi.org/10.1136/bmj.h3037

13. Patel SV, Kidane B, Klingel M, Parry N. Risks associated with red blood cell transfusion in the trauma population, a meta-analysis. Injury 2014;45(10):1522-1533. https://doi.org/10.1016/j. injury.2014.05.015

14. Ferraris VA, Davenport DL, Saha SP, Austin PC, Zwischenberger JB. Surgical outcomes and transfusion of minimal amounts of blood in the operating room. Arch Surg 2012;147(1):49-55. https:// doi.org/10.1001/archsurg.2011.790

15. Mikkola R, Gunn J, Heikkinen J, et al. Use of blood products and risk of stroke after coronary artery bypass surgery. Blood Transfus 2012;10(4):490-501. https://doi.org/10.2450/2012.0119-11

16. Al-Refaie WB, Parsons HM, Markin A, Abrams J, Habermann EB. Blood transfusion and cancer surgery outcomes: A continued reason for concern. Surgery 2012;152(3):344-354. https://doi. surgery outcomes: A contin
org/10.1016/j.surg. 2012.06 .008

17. Khorana AA, Francis CW, Blumberg N, Culakova E, Refaai MA, Lyman GH. Blood transfusions, thrombosis, and mortality in hospitalized patients with cancer. Arch Intern Med 2008;168(21):23772381. https://doi.org/10.1001/archinte. 168.21 .2377

18. Horvath KA, Acker MA, Chang $\mathrm{H}$, et al. Blood transfusion and infection after cardiac surgery. Ann Thorac Surg 2013;95(6):2194-2201. https://doi.org/10.1016/j.athoracsur.2012.11.078

19. Bernard AC, Davenport DL, Chang PK, Vaughan TB, Zwischenberger JB. Intraoperative transfusion of $1 \mathrm{U}$ to $2 \mathrm{U}$ packed red blood cells is associated with increased 30-day mortality, surgical-site infection, pneumonia, and sepsis in general surgery patients. J Am Coll Surg 2009;208(5):931-937, 937.e1-2; discussion 938-939. https://doi.org/10.1016/j.jamcollsurg.2008.11.019

20. Goel R, Patel EU, Cushing MM, et al. Association of perioperative red blood cell transfusions with venous thromboembolism in a North American registry. JAMA Surg 2018;153(9):826-833. https://do. org/10.1001/jamasurg.2018.1565

21. Marik PE, Corwin HL. Efficacy of red blood cell transfusion in the critically ill: A systematic review of the literature. Crit Care Med 2008;36(9):2667-2674. https://doi.org/10.1097/CCM.0b013e3181844677

22. Murphy GJ, Reeves BC, Rogers CA, Rizvi SI, Culliford L, Angelini GD. Increased mortality, postoperative morbidity, and cost after red blood cell transfusion in patients having cardiac surgery. postoperative morbidity, and cost after red blood cell transfusion in patients having cardiac sur
Circulation 2007;116(22):2544-2552. https://doi.org/10.1161/CIRCULATIONAHA.107.698977

23. Xenos ES, Vargas HD, Davenport DL. Association of blood transfusion and venous thromboembolism after colorectal cancer resection. Thromb Res 2012;129(5):568-572. https://doi.org/10.1016/j. thromres.2011.07.047

24. Van Straten AH, Bekker MW, Soliman Hamad MA, et al. Transfusion of red blood cells: The impact on short-term and long-term survival after coronary artery bypass grafting, a ten-year follow-up. Interact Cardiovasc Thorac Surg 2010;10(1):37-42. https://doi.org/10.1510/icvts.2009.214551

25. Paone G, Likosky DS, Brewer R, et al. Transfusion of 1 and 2 units of red blood cells is associated with increased morbidity and mortality. Ann Thorac Surg 2014;97(1):87-93; discussion 93-84. https://doi. org/10.1016/j.athoracsur.2013.07.020

26. Hofmann A, Farmer S, Shander A. Five drivers shifting the paradigm from product-focused transfusion practice to patient blood management. Oncologist 2011;16(Suppl 3):3-11. https://doi. org/10.1634/theoncologist.2011-S3-3

27. Isbister JP, Shander A, Spahn DR, Erhard J, Farmer SL, Hofmann A. Adverse blood transfusion outcomes: Establishing causation. Transfus Med Rev 2011;25(2):89-101. https://doi.org/10.1016/j. tmrv.2010.11.001

28. Carson JL, Carless PA, Hebert PC. Transfusion thresholds and other strategies for guiding allogeneic red blood cell transfusion. Cochrane Database Syst Rev 2012, Issue 4. Art. No.: CD00204. https://doi. org/10.1002/14651858.CD002042.pub3

29. Rohde JM, Dimcheff DE, Blumberg N, et al. Health care-associated infection after red blood cell transfusion: A systematic review and meta-analysis. JAMA 2014;311(13):1317-1326. https://doi. org/10.1001/jama.2014.2726 30. Holst LB, Petersen MW, Haase N, Perner A, Wetterslev J. Restrictive versus liberal transfusion strategy
for red blood cell transfusion: Systematic review of randomised trials with meta-analysis and trial sequential analysis. BMJ 2015;350:h1354. https://doi.org/10.1136/bmj.h1354

31. Salpeter SR, Buckley JS, Chatterjee S. Impact of more restrictive blood transfusion strategies on clinical outcomes: A meta-analysis and systematic review. Am J Med 2014;127(2):124-131.e3. https://doi. org/10.1016/j.amjmed.2013.09.017
32. Carson JL, Stanworth SJ, Roubinian N, et al. Transfusion thresholds and other strategies for guiding allogeneic red blood cell transfusion. Cochrane Database Syst Rev 2016, Issue 10. Art. No.: CD002042. https://doi.org/10.1002/14651858.CD002042.pub4

33. International Foundation for Patient Blood Management. What is patient blood management? https:// www.ifpbm.org (accessed 15 September 2018).

34. World Health Organization. Sixty-Third World Health Assembly, Resolution WHA63.12, Agenda item 11.17 on availability, safety and quality of blood products. 21 May 2010. http://apps.who.int/gb/ebwha/ pdf_files/WHA63/A63_R12-en.pdf (accessed 24 October 2018).

35. Society for the Advancement of Blood Management. Definition of patient blood management. https:// www.sabm.org (accessed 15 September 2018).

36. Mehra T, Seifert B, Bravo-Reiter S, et al. Implementation of a patient blood management monitoring and feedback program significantly reduces transfusions and costs. Transfusion 2015;55(12):28072815. https://doi.org/10.1111/trf.13260

37. Freedman J. The ONTraC Ontario program in blood conservation. Transfus Apher Sci 2014;50(1):32 36. https://doi.org/10.1016/j.transci.2013.12.010

38. Frank SM, Thakkar RN, Podlasek SJ, et al. Implementing a health system-wide patient blood management program with a clinical community approach. Anesthesiology 2017;127(5):754-764. https://doi.org/10.1097/ALN.0000000000001851

39. Gupta PB, DeMario VM, Amin RM, et al. Patient blood management program improves blood use and clinical outcomes in orthopedic surgery. Anesthesiology 2018;129(6):1082-1091. https://doi. org/10.1097/ALN.0000000000002397

40. Leahy MF, Hofmann A, Towler S, et al. Improved outcomes and reduced costs associated with a healthsystem-wide patient blood management program: A retrospective observational study in four majo adult tertiary-care hospitals. Transfusion 2017;57(6):1347-1358. https://doi.org/10.1111/trf.14006

41. Khalafallah AA, Yan C, Al-Badri R, et al. Intravenous ferric carboxymaltose versus standard care in the management of postoperative anaemia: A prospective, open-label, randomised controlled trial. Lance Haematol 2016;3(9):e415-e425. https://doi.org/10.1016/S2352-3026(16)30078-3

42. Froessler B, Palm P, Weber I, Hodyl NA, Singh R, Murphy EM. The important role for intravenous iron in perioperative patient blood management in major abdominal surgery: A randomized controlled in perioperative patient blood management in major abdominal surgery: A rando
trial. Ann Surg 2016;264(1):41-46. https://doi.org/10.1097/SLA.0000000000001646

43. Statistics South Africa. Mid-year population estimates 2018. Statistical release P0302. Pretoria: Stats Satistics South Africa. Mid-year population estimates 2018. Statistical release P0302. Pretoria: S
SA, 2018. https://www.statssa.gov.za/publications/P0302/P03022018.pdf (accessed 28 May 2019).

44. Kassebaum NJ; GBD 2013 Anemia Collaborators. The global burden of anemia. Hematol Oncol Clin Nassebaum NJ; GBD 2013 Anemia Collaborators. The global burden of a
North Am 2016;30(2):247-308. https://doi.org/10.1016/j.hoc.2015.11.002

45. Kassebaum NJ, Jasrasaria R, Naghavi M, et al. A systematic analysis of global anemia burden from 1990 to 2010. Blood 2014;123(5):615-624. https://doi.org/10.1182/blood-2013-06-508325

46. Vos T, Allen C, Arora M, et al. Global, regional, and national incidence, prevalence, and year lived with disability for 310 diseases and injuries, 1990 - 2015: A systematic analysis for the Global Burden of Disease Study 2015. Lancet 2016;388(10053):1545-1602. https://doi.org/10.1016/S01406736(16)31678-6

47. Payne CF, Davies JI, Gomez-Olive FX, et al. Cross-sectional relationship between haemoglobin concentration and measures of physical and cognitive function in an older rural South African population. J Epidemiol Community Health 2018;72(9):796-802. https://doi.org/10.1136/jech-2018210449

48. Fowler AJ, Ahmad T, Phull MK, Allard S, Gillies MA, Pearse RM. Meta-analysis of the association between preoperative anaemia and mortality after surgery. Br J Surg 2015;102(11):1314-1324. https:/ doi.org/10.1002/bjs. 9861

49. Munoz M, Gomez-Ramirez S, Kozek-Langeneker S, et al. 'Fit to fly': Overcoming barriers to preoperative haemoglobin optimization in surgical patients. Br J Anaesth 2015;115(1):15-24. https:/ doi.org/10.1093/bja/aev165

50. Marsicano D, Hauser N, Roodt F, et al. Preoperative anaemia and clinical outcomes in the South African Surgical Outcomes Study. S Afr Med J 2018;108(10):839-846. https://doi.org/10.7196 SAMJ.2018.v108i10.13148

51. Joint United Nations Programme on HIV and AIDS. Country overview South Africa. http://www. unaids.org/en/regionscountries/countries/southafrica (accessed 15 September 2018 2018).

52. United Nations DESA/Population Division. World population prospects: The 2017 revision. 2017. https://esa.un.org/unpd/wpp/ (accessed 15 October 2018).

53. Horton S, Ross J. The economics of iron deficiency. Food Policy 2003;28(1):51-75. https://doi org/10.1016/S0306-9192(02)00070-2

54. Munoz M, Gomez-Ramirez S, Besser M, et al. Current misconceptions in diagnosis and management of iron deficiency. Blood Transfus 2017;15(5):422-437. https://doi.org/10.2450/2017.0113-17

55. Froessler B, Rueger AM, Connolly MP. Assessing the costs and benefits of perioperative iron deficiency anemia management with ferric carboxymaltose in Germany. Risk Manag Healthc Policy 2018;11:77 82. https://doi.org/10.2147/RMHP.S157379

6. Klein HG, Hrouda JC, Epstein JS. Crisis in the sustainability of the U.S. blood system. N Engl J Med 2017;377(15):1485-1488. https://doi.org/10.1056/NEJMsb1706496

57. Meybohm P, Froessler B, Goodnough LT, et al. 'Simplified International Recommendations for the Implementation of Patient Blood Management' (SIR4PBM). Perioper Med 2017;6:5. https://doi. org/10.1186/s13741-017-0061-8

58. Althoff FC, Neb H, Herrmann E, et al. Multimodal patient blood management program based on a three-pillar strategy: A systematic review and meta-analysis. Ann Surg 2019;269(5):794-804. https:// doi.org/10.1097/SLA. 0000000000003095

59. Van der Linden P, Hardy JF. Implementation of patient blood management remains extremely variable in Europe and Canada: The NATA benchmark project. Eur J Anaesthesiol 2016;33(12):913-921. https://doi.org/10.1097/EJA.0000000000000519

60. Carson JL, Triulzi DJ, Ness PM. Indications for and adverse effects of red-cell transfusion. N Engl Med 2017;377(13):1261-1272. https://doi.org/10.1056/NEJMra1612789

61. Katz LM, Donnelly JJ, Gresens CJ, et al. Report of a workshop on ensuring sustainable access to safe blood in developing countries: International Blood Safety Forum, March 24, 2017. Transfusion 2018;58(5):1299-1306. https://doi.org/10.1111/trf.14591

62. Sood R, Raykar N, Till B, Shah H, Roy N. Walking blood banks: An immediate solution to rural India’s blood drought. Indian J Med Ethics 2018;3(2):134-137. https://doi.org/10.20529/IJME.2017.098

63. Spiegel DA, Droti B, Relan P, Hobson S, Cherian MN, O'Neill K. Retrospective review of surgical availability and readiness in 8 African countries. BMJ Open 2017;7(3):e014496. https://doi. org/10.1136/bmjopen-2016-014496

64. Jain Y, Kataria R. Rural blood availability: Regulations must meet ethics. Indian J Med Ethics 2016;1(4):237-242. https://doi.org/10.20529/IJME.2016.068

65. Hussein J, Hirose A, Owolabi O, Imamura M, Kanguru L, Okonofua F. Maternal death and obstetric care audits in Nigeria: A systematic review of barriers and enabling factors in the provision of emergency care. Reprod Health 2016;13:47. https://doi.org/10.1186/s12978-016-0158-4

66. Pitman JP, Wilkinson R, Basavaraju SV, et al. Investments in blood safety improve the availability of blood to underserved areas in a sub-Saharan African country. ISBT Sci Ser 2014;9(2):325-333. https:/ doi.org/10.1111/voxs.12107

67. Compaore GD, Sombie I, Ganaba R, et al. Readiness of district and regional hospitals in Burkina Faso to provide caesarean section and blood transfusion services: A cross-sectional study. BMC Pregnancy Childbirth 2014;14:158. https://doi.org/10.1186/1471-2393-14-158 
68. Lund TC, Hume H, Allain JP, McCullough J, Dzik W. The blood supply in sub-Saharan Africa: Needs, challenges, and solutions. Transfus Apher Sci 2013;49(3):416-421. https://doi.org/10.1016/j. transci.2013.06.014

69. Dzik WS, Kyeyune D, Otekat G, et al. Transfusion medicine in Sub-Saharan Africa: Conference summary. Transfus Med Rev 2015;29(3):195-204. https://doi.org/10.1016/j.tmrv.2015.02.003

70. Chevalier MS, Kuehnert M, Basavaraju SV, Bjork A, Pitman JP. Progress toward strengthening national blood transfusion services - 14 countries, 2011 - 2014. MMWR Morb Mortal Wkly Rep 2016;65(5):115-119. https://doi.org/10.15585/mmwr.mm6505a

1. Vamvakas EC. Establishing causation in transfusion medicine and related tribulations. Transfus Med Rev 2011;25(2):81-88. https://doi.org/10.1016/j.tmrv.2010.11.010

72. Custer B, Hoch JS. Cost-effectiveness analysis: What it really means for transfusion medicine decision making. Transfus Med Rev 2009;23(1):1-12. https://doi.org/10.1016/j.tmrv.2008.09.001

73. Hofmann A, Ozawa S, Farrugia A, Farmer SL, Shander A. Economic considerations on transfusion medicine and patient blood management. Best Pract Res Clin Anaesthesiol 2013:27(1):59-68. https:// doi.org/10.1016/i.bpa.2013.02.001

74. Anthes E. Evidence-based medicine: Save blood, save lives. Nature 2015;520(7545):24-26. https://doi. org $/ 10.1038 / 520024 a$

75. Spahn DR, Theusinger OM, Hofmann A. Patient blood management is a win-win: A wake-up call. Br J Anaesth 2012;108(6):889-892. https://doi.org/10.1093/bja/aes166

76. Australian Commission on Safety and Quality in Health Care. The National Patient Blood Management Australian Commission on Safety and Quality in Health Care. The National Patient Blood Management
Collaborative. https://www.safetyandquality.gov.au/national-priorities/pbm-collaborative/ (accessed Collaborative. https://www.safetyandquality.gov.au/national-priorities/pbm-collaborative/ (accessed 3 February 2018

77. National Blood Authority, Australia. Patient Blood Management Guidelines: Module 1. Critical bleeding/massive transfusion. 1 March 2011. http://www.blood.gov.au/pbm-module-1 (accessed 15 September 2018)

78. National Blood Authority, Australia. Patient Blood Management Guidelines: Module 2. Perioperative. 9 March 2012. http://www.blood.gov.au/pbm-module-2 (accessed 15 September 2018).

79. National Blood Authority, Australia. Patient Blood Management Guidelines: Module 3. Medical. 19 September 2012. http://www.blood.gov.au/pbm-module-3 (accessed 15 September 2018).
80. National Blood Authority, Australia. Patient Blood Management Guidelines: Module 4. Critical care. April 2013. http://www.blood.gov.au/pbm-module-4 (accessed 15 September 2018).

81. National Blood Authority, Australia. Patient Blood Management Guidelines: Module 5. Obstetrics and maternity. 23 March 2015. https://www.blood.gov.au/pbm-module-5 (accessed 15 September 2018).
molics

82. National Blood Authority, Australia. Patient Blood Management Guidelines: Module 6. Neonatal and paediatrics. 29 April 2016. https://www.blood.gov.au/pbm-module-6 (accessed 15 September 2018).

83. Society for the Advancement of Blood Management. SABM Administrative and Clinical Standards . Society for the Advancement of Blood Management. SABM Administrative and Clinical Standards
for Patient Blood Management Programs. 4th ed. 2017. https://www.sabm.org/publications/ (accessed 15 September 2018)

84. Gombotz H, Hofmann A, Nørgaard A, Kastner P. Supporting Patient Blood Management (PBM) in the EU: A Practical Implementation Guide for Hospitals. Brussels: European Commission, DirectorateGeneral for Health and Food Safety, 2017. https://publications.europa.eu/en/publication-detail/-I publication/93elbbbf-1a8b-11e7-808e-01aa75ed71a1/language-en (accessed 28 May 2019).

85. Hofmann A, Nørgaard A, Kurz J, et al. Building National Programmes on Patient Blood Management (PBM) in the EU: A Guide for Health Authorities. Brussels: European Commission, DirectorateGeneral for Health and Food Safety, 2017.

86. Vaglio S, Gentili S, Marano G, et al. The Italian regulatory guidelines for the implementation of patient blood management. Blood Transfus 2017;15:325-328. https://doi.org/10.2450/2017.0060-17

87. Vaglio S, Prisco D, Biancofiore G, et al. Recommendations for the implementation of a patient blood management programme: Application to elective major orthopaedic surgery in adults. Blood Transfus 2015;14:23-65. https://doi.org/10.2450/2015.0172-15

88. American Association of Blood Banks Standards Program Committee. Standards for a Patient Blood Management Program. 2nd ed. AABB, 2018.

89. Hofmann A, Friedman D, Farmer S. Western Australia Patient Blood Management Project 2008 - 2012, Analysis, Strategy, Implementation and Financial Projections. Perth, Western Australia: Medicine and Economics, 2007.

Accepted 7 May 2019. 